\title{
The Establishment of the Conservatory
} of the Glasbena Matica in Ljubljana in the Context of the Construction of Central National Musical Institutions*

\author{
Jernej Weiss \\ Univerza v Ljubljani / Univerza v Mariboru \\ University of Ljubljana / University of Maribor
}

At the turn of the century and up until the beginning of the First World War, the musical pulse of Ljubljana was beating stronger than ever. The unique rivalry between its two competing musical institutions resulted in new achievements, and the circumstances of that time allowed them both to shine in their own way: the Glasbena Matica music society excelled principally in the choral field, while the Philharmonische Gesellschaft (Philharmonic Society), established in 1794, led the way in the performance of chamber and symphonic music. ${ }^{1}$ However, the conflicts and increasingly apparent divisions between the two key political perspectives in Slovenia, the liberals and the clericalists, had already begun to interfere in the lives of these two cultural institutions in the years leading up to the Great War and were to have fateful consequences in 1913.

Various scandals on the clericalist side, which the liberals made very good use of, appear to have prompted the conservatives to take their revenge on the "liberal institutions", which needed the support of the provincial government, where the conservatives had a majority. As a result, they withdrew their support from the Glasbena Matica, having already done the same to the Slovenian Philharmonic and the Slovene theatre company at the Provincial Theatre. Despite emphasising that the management

This article is a part of the research project nr. J6-8261, financed by the Slovenian Research Agency from the state budget.

1 Darja Koter, Slovenska glasba 1848-1918 (Ljubljana: Študentska založba, 2012), 267. 
of cultural institutions should be a cultural rather than political issue for all Slovenes, the Provincial Council maintained its views. ${ }^{2}$

The result was devastating: the Slovenian Philharmonic (which under the leadership of Václav Talich had notched up several enviable artistic achievements from 1908 to 1912) was no more, the Slovene theatre and opera companies based at the Provincial Theatre ceased their activities, and the most important music periodical Novi akordi ("New Chords"), the final issues of which had begun dealing with certain critical concerns regarding Slovene music, ceased publication. Its Vienna editor Gojmir Krek stood out against the "rotten circumstances"' in Slovene cultural policy.

The Glasbena Matica music society in Ljubljana managed to survive and strove to follow a non-party policy, but neither side was happy with this. ${ }^{4}$ Negative views regarding the Glasbena Matica are also evident from numerous newspaper reports of the time. Ivan Štefe, a journalist at Slovenec ("The Slovene"), then the leading newspaper of political Catholicism in Slovenia, wrote these harsh words: "Although we will not attack the Glasbena Matica outright, our ultimate aim is to destroy it."

Such a position against the main sponsor of the majority of Slovene music societies naturally could not have had a favourable impact on the growth and development of Slovene musical culture. It may therefore be said that the Slovenes were their own worst enemy as far as pre-war musical culture was concerned, since discord, factionalism and mutual opposition were what caused the most damage to musical development and the progress of Slovenia's burgeoning music culture.

The venerable Philharmonic Society in Ljubljana faced no such problems, at least not to an extent that would seriously jeopardise its normal functioning. Despite the impending war, its membership continued to grow, ${ }^{6}$ and Philharmonic concerts were conducted more or less undisturbed. In this regard, the testimony of a German living in Celje, Fritz

2 Primož Kuret, Ljubljanska filharmonična družba 1794-1919: kronika ljubljanskega glasbenega življenja $v$ stoletju meščanov in revolucij (Ljubljana: Nova revija, 2005), 406 .

3 Gojmir Krek, "Dostavek uredništva," Novi akordi: glasbeno-književna priloga 13, no. 1 (1914): 23.

Nataša Cigoj Krstulović, Zgodovina, spomin, dediščina: ljubljanska Glasbena matica do konca druge svetovne vojne (Ljubljana: Založba ZRC, 2015), 85-92.

5 Kuret, Ljubljanska filharmonična družba, 406.

6 As an example, nearly the entire officers' choir of the 27 th Infantry Regiment in Ljubljana joined the Ljubljana Philharmonic Society. Kuret, Ljubljanska filharmonična družba, 408. 
Zangger, is worthy of note; Zangger wrote that "the social and cultural life of Ljubljana before the First World War was at an enviable level." He even believed that no other similar-sized city in the Monarchy could compare with Ljubljana in this regard, which appears somewhat exaggerated given the vibrant cultural life of some of the other cities in the Austro-Hungarian Monarchy.

The work of the Philharmonic Society, which alongside the German theatre company at the Provincial Theatre was still the principal music institution in Slovenia, was influenced more heavily by certain management-related changes, as the conclusion of the 1911/12 season saw the long-serving music director of the Philharmonic Society, Josef Zöhrer, announce his retirement. The leadership was now assumed by the elderly concertmaster Hans Gerstner, ${ }^{8}$ who from the autumn of 1914 to late June 1919 was responsible for virtually everything connected with the work of the Philharmonic Society in Ljubljana. ${ }^{9}$

All the more evident and, for the many musicians from the German cultural milieu then working in Slovenia, all the more painful, was the rupture in the music scene that followed the First World War, when the Philharmonische Gesellschaft saw its status utterly reduced, paving the way for its eventual incorporation into the Glasbena Matica as the Filharmonično društvo on 19 July 1921 (although it was not formally abolished until 1945). ${ }^{10}$ The main Philharmonic Hall, the Tonhalle, shared the ignominious fate of its erstwhile administrator. In the immediate post-war years it was used as storage premises, while in 1923 it was taken over by the Kino Matica cinema company. The magnificent past of the Philharmonic Society was thus cast onto the scrapheap of history practically overnight. An attempt to take over the supremely important role it had hitherto played in musical culture in Slovenia was made by the Glasbena Matica, which henceforth had an almost complete monopoly.

$7 \quad$ Fritz Zangger, Das ewige feuer im fernen Land: Ein deutsches Heimatbuch aus dem Südosten (Celje: Druckerei u. Verlags AG, 1937), 98.

8 In a typescript dated as early as 20 October 1910, the management asked Gerstner to take over responsibility for the philharmonic orchestras, a task that was said to be of great artistic and national importance. Die Philharmonische Gesellschaft in Laibach, 20 October 1910, Ljubljana, Gesellschaft der Musikfreunde in Wien, Archiv. not Fade Away Completely: The Concert Life of the Philharmonic Society in Ljubljana in the Period of its Last Music Director Hans Gerstner," Muzikološki zbornik 53, no. 2 (2017): 149-171. 
The situation at the (German) Provincial Theatre in Ljubljana was even more complex. With the opening in the autumn of 1911 of the new German theatre dedicated to the Emperor Franz Joseph (henceforth known as the Deutsches Theater), the German theatre company at the Provincial Theatre realised its long-cherished ambition of wresting itself from the grip of its Slovene counterpart, which was increasingly limiting its activity and gradually driving it out of its original home. Previously both companies had been housed at the same location - the Provincial Theatre - where they shared "performance days". "Thus in the 1911/12 season, both Germans and Slovenes achieved their long-held desire to have their own theatre, although this did not guarantee the survival of either company. While the predominantly liberally oriented Slovene management faced the aforementioned internal political pressures, the Germans found themselves losing out in an increasingly Slovene Ljubljana ${ }^{12}$ that was too small to sustain two theatrical institutions. In turn, these factors led to the closure of both theatres, which had shaped the musical and dramatic image of the capital for two decades prior to the First World War.

\section{Nationalisation of music institutions after the First World War}

Like other cultural institutions in the capital, the musical sphere was characterised in the post-war years by two simultaneous processes: the nationalisation and Slovenisation of formerly "German" musical institutions. The newly founded Education and Religious Worship Commission (Poverjeništvo za uk in bogočastje) of the National Government (later the Provincial Government for Slovenia), headed by Karel Verstovšek operated a rather restrictive cultural policy with regard to German cultural institutions. ${ }^{13}$ During the period in which it operated, from October 1918 to November 1921, it introduced radical changes both in education and in the cultural sphere, which also affected the functioning of individual musical institutions in Slovenia. ${ }^{\mathrm{I}}$

11 Špela Lah, "Slovensko-nemška dihotomija v Deželnem gledališču v Ljubljani med letoma 1892 in 1914," Muzikološki zbornik 46, no. 2 (2010): 97.

12 Dragan Matić, Nemci v Ljubljani: 1861-1918 (Ljubljana: Oddelek za zgodovino Filozofske fakultete, 2002): 433 .

13 Aleš Gabrič, "Ustanovitev Opere Narodnega gledališča v Ljubljani v sklopu izgradnje osrednjih narodnih kulturnih ustanov," Studia musicologica Labacensia 3 (2019): 279.

14 Ervin Dolenc, "Karel Verstovšek kot poverjenik za uk in bogočastje v narodni in deželni 


\section{Opera of the National Theatre in Ljubljana}

While the operatic muses had remained silent in Ljubljana during the First World War, on 6 April 1918 - before the conflict had even ended - Ljubljana mayor Ivan Tavčar announced in the newspaper Slovenski narod ("The Slovene Nation"), under the bombastic headline "Slovenes!", that "a consortium has been established for the purpose of reviving the Slovene theatre in Ljubljana and creating a solid financial basis for it." ${ }^{\text {'s }}$ A board of directors was appointed, consisting of representatives of politics and capital. The consortium was headed by the wholesale merchant Alojzij Lilleg and a theatrical council, which included some leading representatives of the Slovene cultural community of that time: Anton Funtek, Matej Hubad, Fran Saleški Finžgar, Alojz Kraigher, Oton Župančič and Izidor Cankar. Undoubtedly the biggest contribution to the revival of the theatre came from Fran Govekar, who brought together the necessary technical staff, singers, orchestra, chorus and conductors. It was also thanks to his personal efforts that a Slovene opera and ballet company began its activity with the operetta Les p'tites Michu (The Little Michus) by André Messager on 21 November $1918 .{ }^{16}$

Like the first post-war play to be staged in the former Deutsches Theater - Josip Jurčičss Tugomer, whose performance in Ljubljana was prohibited in Austro-Hungarian times - the choice of Smetana's The Bartered Bride as the first post-war opera performance at the National Theatre Opera House in Ljubljana (on 3 December 1918) was no coincidence. Given the more than 50 performances of this work at the (Slovene) Provincial Theatre before the start of the First World $\mathrm{War}^{17}$, it could almost be characterised as Slovenia's second "national" opera. Like so many times before, the production illustrated the connection between the Slovene and Czech nations and was at the same time an acknowledgement of the fraternal assistance of Czech artists to the benefit of Slovene theatre. ${ }^{18}$ In this connection it should also be mentioned that Smetana's countryman Anton Foerster, who lived and worked in Slovenia, closely modelled his own opera Gorenjski slavček (The

vladi v Ljubljani 1918-1920," Časopis za zgodovino in narodopisje 66, no. 2 (1995): 284291.

15 Ivan Tavčar, “Slovenke in Slovenci!” Slovenski narod 51, no. 78 (6 April 1918): 1.

16 Dušan Moravec, ed., Repertoar slovenskih gledališč 1867-1967 (Ljubljana: Slovenski gledališki muzej, 1967), 204.

17 Ibid., 181-201.

18 Jernej Weiss, Češki glasbeniki v 19. in na začetku 2o. stoletja na Slovenskem (Maribor: Litera and Univerza v Mariboru, 2012), 362-370. 
Carniolan Nightingale) on The Bartered Bride, incorporating folk songs, a rural setting and, last but not least, the problems faced by emigrants. ${ }^{19}$

The day after the first performance, on 3 December 1918, an anonymous critic wrote in the newspaper Slovenski narod ("The Slovene Nation") that with the staging of The Bartered Bride the "new Slovene opera theatre has celebrated its resurrection." The critic continued that after the initial successes at the new Provincial Theatre, Slovene opera "had been in decline, until present circumstances reduced it to a point where it appeared dead."21 But this was now surely a thing of the past, for "yesterday we saw it again and it appeared virtually finer than in the finest period of its existence!"22

Despite some promising reviews, the first season (1918/19) of the National Theatre Opera in Ljubljana did not yet bring the desired changes in terms of personnel, organisation and programme. Accordingly, the later nationalisation was welcomed by everyone, in particular by the opera company's management and the staff of the theatre, who would no longer be so dependent on unreliable and rapidly changing conditions, nor as obliged to count on foreign members of the company as they had been to date. Following the nationalisation of the theatre, the theatre's general manager Friderik Juvančič noted optimistically in the programme published on 5 August 1920, ahead of the 1920/21 season, that "The personnel of the opera has been significantly augmented", and listed the names of the seven opera singers and two ballet dancers who had recently joined the company. ${ }^{23}$

\section{Conservatory of the Glasbena Matica in Ljubljana}

An even more decisive step towards the more sustainable realisation of musical activity in the capital was taken with the establishment of the Conservatory of the Glasbena Matica in Ljubljana. This was the fruit of long years of efforts by Slovenes to raise the level of music education and professionalise musical life. These efforts were revived after the Great War by Matej Hubad, the concert director of the Glasbena Matica and later direc-

19 Jernej Weiss, "Med provincialno opereto in nacionalno opero Foersterjev Gorenjski slavček," in Musica et artes: ob osemdesetletnici Primoža Kureta, ed. Jonatan Vinkler and Jernej Weiss (Koper, Ljubljana: Založba Univerze na Primorskem, Akademija za glasbo, Festival Ljubljana, Slovenska filharmonija, 2015), 66-70.

Anon., "Narodno gledališče," Slovenski narod, no. 288 (4 December 1918): 3.

Ibid.

Ibid.

Friderik Juvančič, "Sezona 1920-21," Gledališki list Narodnega gledališča 1, no. 1 (1920-21): 14 . 
tor of the Conservatory. He believed that the numbers enrolled at the Glasbena Matica school and the existing teaching staff already met the necessary conditions to raise the school to a higher level, and began discussions to this end with the Provincial Government.

He also advocated in favour of the Conservatory through newspaper articles in which he tirelessly promoted the initiative. In an article entitled "The Yugoslav Conservatory of the Glasbena Matica in Ljubljana" for the teachers' newspaper Učiteljski tovariš ("The Teacher's Companion"), he included the following among the various tasks of the nascent establishment:

The Conservatory should be a cultural temple of the musical, operatic and dramatic arts. It should liberate, promote and sedulously cultivate its own Yugoslav musical culture to the highest pitch of perfection, thereby enabling it to compete with the other cultural nations of the world. ${ }^{24}$

In keeping with the new cultural and political reality, the adjective "Yugoslav" began to appear increasingly frequently alongside the adjective "Slovene". In the same article, Hubad noted that the country had sufficient home-grown talent, but that the establishment of the Conservatory would satisfy one of the fundamental conditions for the more rapid progress not only of Slovene but of pan-Yugoslav musical culture. This would raise music education to a higher level capable of satisfying the new state's needs with regard to the development of musical creativity. ${ }^{25}$

On 21 May 1919 it became apparent that Hubad's ideas had fallen on fertile ground. On that day, the board of the Glasbena Matica decided that the society would begin to offer teaching at the pre-conservatory level. At the same time, it was decided that the music school attached to the Philharmonic Society would be incorporated into the Glasbena Matica's own music school. In mid-September that same year, the dates of entrance examinations in piano, violin, singing, harmony and counterpoint, and drama were announced in Slovenski narod. ${ }^{26}$ At the next meeting of the board, Hubad was able to report that - even before the end of the deadline for admissions - the number of candidates wishing to enrol had increased so much that there were not enough teachers for the just under 200 piano

24 Matej Hubad, “Jugoslovanski konservatorij Glasbene Matice v Ljubljani,” Učiteljski tovariš 59, no. 35 (27 August 1919): 1.

25 Ibid.

26 "Konservatorij 'Glasbene Matice," Slovenski narod 52, no. 214 (14 September 1919): 5, http://www.dlib.si/?URN=URN:NBN:SI:DOC-9RCZI5KT. 
and violin students. In the 1919/20 academic year, a total of more than 1,00o students enrolled at the Glasbena Matica school, which henceforth consisted of a four-year preliminary or lower level, an intermediate level and a three-year higher level. ${ }^{27}$ Students wishing to study music on an amateur basis enrolled at the music school of the Glasbena Matica, while those enrolling at the Conservatory for the most part wished to pursue music professionally.

Initial enrolment at all three levels thus immediately exceeded even the most optimistic predictions, but less attention was paid to the provision of the necessary financial resources for the functioning of the Conservatory. To begin with, the Glasbena Matica received practically no help from the state to sustain the existence of the Conservatory. The only support came from the Provincial Government for Slovenia, although the sum of 20,000 krona provided by the latter ${ }^{28}$ was largely symbolic.

Efforts to settle the status of the Conservatory on a more permanent footing yielded more significant results on 5 January 1920, when the Education and Religious Worship Commission, at that time the principal state body in the field of culture, granted the Conservatory the right to issue state-approved certificates. ${ }^{29}$ As a result, the Glasbena Matica became the de facto principal organiser of music education, not only in Ljubljana but in the whole of Slovenia.

The growing number of students and teachers, combined with the expanding curriculum, naturally led to an increase in the Conservatory's operating costs. The undeniable importance of the subsequent nationalisation for the Conservatory's functioning and, indeed, survival is shown by the figures for 1921. At that time the institution already had almost 50 teachers on its payroll - full-time professors, full-time and part-time teachers, honorary professors and supply teachers, most of whom taught at all three levels, although a few taught at only one level. The Conservatory's annual operating costs already exceeded one million krona, with just under 700,000 krona covered by fees. Until nationalisation, the Conservatory's budget thus showed a shortfall of around 300,00o krona, which had to be made

27

28

Cigoj Krstulović, Zgodovina, spomin, dediščina, 167.

Cvetko Budkovič, Razvoj glasbenega šolstva na Slovenskem II: od nastanka konservatorija do Akademije za glasbo 1919-1946 (Ljubljana: Znanstveni inštitut Filozofske fakultete, 1995): 22.

9 "Podelitev pravice javnosti," Uradni list deželne vlade za Slovenijo II, no. 7 (16 January 1920): 30, https://www.sistory.si/cdn/publikacije/1-10oo/210/Uradni_list_SHS_1920. pdf. 


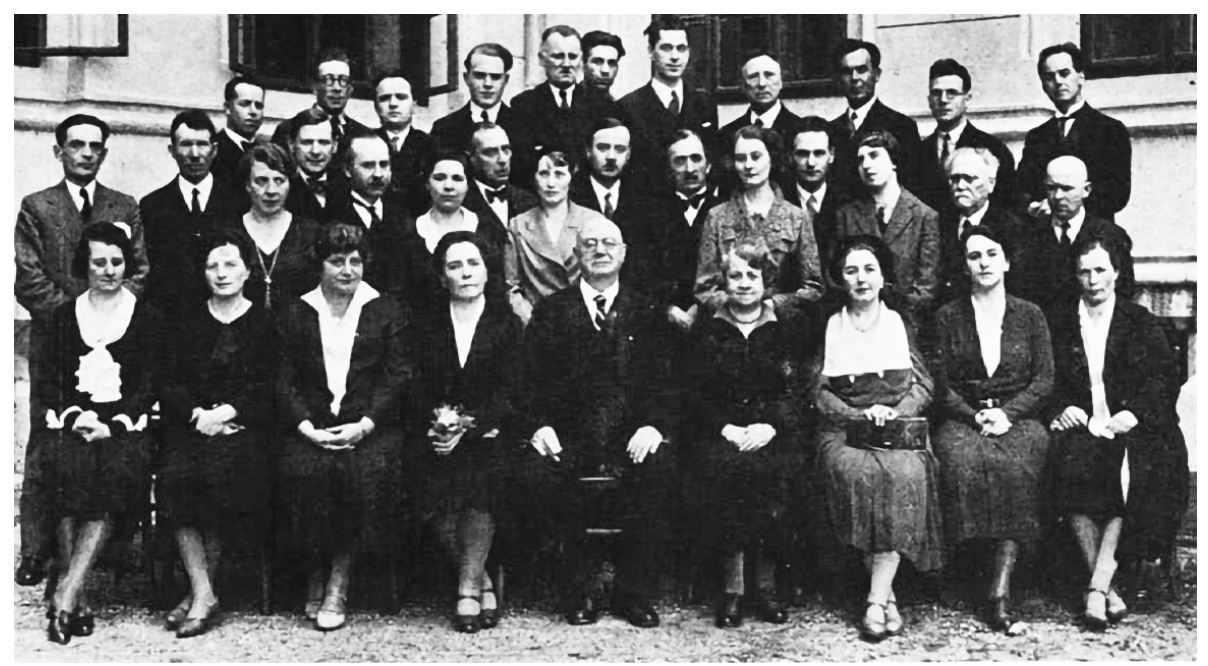

Picture I: Teaching staff of the Glasbena Matica music school and the State Conservatory in 1932 (National and University Library, Music Collection, Glasbena Matica archives, http://www.dlib.si/?URN=URN:NBN:SI:DOC-SO9IQWOY, 3).

up from other sources. ${ }^{30}$ The state gradually took over a larger share of the Conservatory's funding. It was renamed the State Conservatory in 1926, following nationalisation, and beginning in the 1926/27 academic year was funded entirely by the state.

That the initial financial situation of the Conservatory was anything but favourable is also evident from the fact that in its first years of operation the management could only afford to regularise a few of its full-time teaching positions. Hubad was appointed director and was allowed to choose his own closest collaborators. Two other professorial appointees besides Hubad (who taught singing) were Janko Ravnik (piano) and Josip Vedral (violin and chamber music). Over the following years Jan Šlais (violin), Julij Betetto (singing), Dana Kobler (piano) and Karel Jeraj (violin) joined the full-time staff of the Conservatory. Karel Jeraj - like Julij Betetto - had an impressive international career behind him, including a period as concertmaster of the State Opera Orchestra in Vienna, where in 1900 he played under the direction of Gustav Mahler.

As well as Hubad (middle of the front row, seated), the photograph shows the most important Slovene musicians of the interwar period, including Janko Ravnik, considered the father of Slovene piano teaching 30 Budkovič, Razvoj glasbenega šolstva na Slovenskem II, 24-25. 
(back row, first from the right) and Slavko Osterc (middle row, first from the right). On Osterc's right is Emerik Beran, Osterc's first teacher, now quite elderly, whom Hubad had invited to the Conservatory in 1927 to teach cello. Even before this, Hubad regularly consulted Beran on questions related to teaching. Beran was one of the most experienced teachers at the Conservatory. Two of his cello syllabuses from this period have been preserved. These were based on the existing syllabus of the men's teacher training college in Maribor (Državno moško učiteljišče v Mariboru, formerly the k. k. Lehrerbildungsanstalt Marburg), where he had taught previously. ${ }^{31}$ This syllabus was, in turn, modelled on those of the Organ School in Brno, where Beran himself had trained, a circumstance which demonstrates how the pedagogical models adopted in Ljubljana did not originate exclusively in the conservatories of Prague and Vienna. In addition to teaching cello (like the other teachers, he was required to teach 20 hours a week and, in the event of an insufficient number of hours of cello lessons, to teach piano as well), Beran shared responsibility for ensemble rehearsals at the State Conservatory with Jan Šlais. He was frequently disappointed at the standard of the Conservatory's students and admonished them that under Leoš Janáček in Brno they would not have passed the year. ${ }^{32}$

The relatively low standard of students in the first years of the Conservatory's operation may to a certain extent be linked to the lack of adequately qualified teachers. It appears that Hubad devoted the majority of his time to seeking suitable staff across the whole of the new state. In the immediate post-war years he also made several visits to the conservatories in Zagreb and Prague. A vivid picture of the modest pedagogical conditions in the first post-war years is provided in an autobiographical account by Vida Jeraj-Hribar, the daughter of the already mentioned Karel Jeraj, later a teacher at the Ljubljana Conservatory and the founder of the Glasbena Matica Orchestral Society (Orkestralno društvo Glasbene matice). In 1919, having studied the violin at the Vienna Conservatory for two years, JerajHribar decided to continue her studies in Ljubljana. Recalling this time in later years, she wrote:

31 Jernej Weiss, Emerik Beran (1868-1940): samotni svetovljan (Maribor: Litera, 2008): 65.

32 Ibid., 67. 
I suffered, because studies in my homeland were not to Viennese standards. The complementary subjects were fit for dilettantes. Requirements were minimal. . $^{33}$

Given the considerable number of violin and piano students, the time available for individual lessons was initially limited to just three 20-minute sessions per week, which was far from adequate for good-quality work. Despite criticisms of this type, which draw attention to certain inadequacies in the initial teaching provided by the Conservatory, it should nevertheless be pointed out that requirements differed and that in any case they were always dependent on the individual teacher. Emerik Beran, for example, frequently offered extra lessons to his most gifted students - such as Oton Bajde and Bogo Leskovic - and in this way succeeded in training a large number of first-class cellists.

The late 1920 s was also the period in which the first public criticism of the work of the Conservatory began to be heard. The harshest critic of some of the perceived inadequacies was the art historian and critic Stanko Vurnik, writing in the monthly Dom in svet ("Home and World"). He advocated the modernisation of the Conservatory and a thorough overhaul of its curriculum, teaching methods and teaching material that would enable a development from "artisanal" skills to the training of "musical intelligence in the higher sense of artistic education." In his view: "The Conservatory should train young composers of modern orientation and thought!" Vurnik also frequently addressed questions of musical aesthetics and observed that "the Croats are already ahead of $u s "{ }^{34}$ The Glasbena Matica did not expect such words, which caused considerable indignation and sparked a well-known newspaper controversy between the composer and Conservatory professor Lucijan Marija Škerjanc and Vurnik, who was joined by the composer Vilko Ukmar and France Marolt, the director of the University's Academic Choir. In the end the Glasbena Matica's prime mover Anton Lajovic intervened with a conciliatory piece in Jutro ("Morning"). ${ }^{35}$

Vurnik reproached the Conservatory's management with the fact that students were insufficiently prepared for their end-of-year performances,

33 Vida Jeraj-Hribar, Večerna sonata. Spomini z Dunaja, Pariza in Ljubljane 1902-1903, as told to Marijan Kovačevič (Ljubljana: Mladinska knjiga, 1992), 58-59.

34 Stanko Vurnik, "Glasba: Slovensko glasbeno življenje l. 1928," Dom in svet 42, no. 1-2 (1929): 63-64.

35 Anton Lajovic, "Kulturni pregled: Naša glasbena kritika." Jutro 10, no. 155 (6 July 1929): 6. 
that the same compositions were constantly repeated and that the teaching material was out of date. It appears that criticisms of this kind prompted a far-reaching overhaul of teaching at the Conservatory a few years later, when Julij Betetto took over as director in 1933 and called on his teachers to make changes. ${ }^{36}$

Up to this time the institution had mainly focused on singing (solo and choral), while instrumental lessons were centred above all on piano and violin. The reports of the Glasbena Matica on the work of the Conservatory show that, despite the efforts of the board to teach the widest possible range of instruments and thus boost orchestral playing, by far the greatest interest was in learning the piano; there was practically no interest in woodwind, brass and percussion. On the other hand, the range of compulsory theoretical subjects (counterpoint, harmony, musical form, instrumentation, history of music, aesthetics of music, ensemble rehearsals, etc.) was conceived relatively broadly, to enable students to acquire the widest possible musical education. After nationalisation, the higher level course at the Conservatory consisted of four years (previously three), while the composition and conducting department offered a fiveyear course. Teaching at the high level also included piano, violin, cello and (solo) singing. ${ }^{37}$

Vurnik's criticism was unquestionably also directed at the fact that the Conservatory did not offer master's level courses. This meant that until the founding of the Academy of Music, Conservatory students were obliged to leave the country in order to continue their training at the master's level. Almost all of Osterc's composition students, for example, pursued master's studies at the State Conservatory in Prague.

As early as the mid-1920s, then, Vurnik was advocating the introduction of the highest standards in music teaching, performance and composition at the Conservatory - something that had not previously been possible for financial, staffing and other material reasons. Although in many ways justified, Vurnik's comparisons with the courses offered by some of the most important institutions of higher musical education, boasting a tradition dating back more than a century, appear to be somewhat premature. It was only with the establishment of the Music Academy (Glasbena akademija) in 1939 - unlike the Conservatory, the new Academy had university college status - and even more so after the end of the Sec-

36 Cigoj Krstulović, Zgodovina, spomin, dediščina, 172.

37 Ibid., 169. 
ond World War, that conditions for music-making in Slovenia had matured to the extent that Vurnik's lofty aesthetic demands could begin to be met and it gradually became possible to train instrumental virtuosi and composers.

Be that as it may, the establishing of the Conservatory already represented the first significant contact with contemporary achievements in other countries at the higher level of music education. Despite the modest conditions in which it operated, the Conservatory achieved significant and indeed enviable successes in some fields (such as Janko Ravnik's piano class, Jan Šlais's violin class or Julij Betetto's vocal class). Up until the Second World War, it was the only arts education institution in Slovenia to award state-approved diplomas, since plans to establish similar schools for the theatre and fine arts were not realised until after the war.

Nationalisation meant the first major turning point in the work of the Conservatory. If at the start of the 1920 s the composer and critic Marij Kogoj, despite his belief in an eventual "victory", could only hope that nationalisation would soon bring the fresh wind needed to boost Slovene musical culture, ${ }^{38}$ a few years later his successor as critic at Dom in svet, Stanko Vurnik, was already offering a critical assessment of all aspects of the work of the Conservatory and a number of other musical institutions. Which meant that the previously burning question of the survival of individual musical institutions in Slovenia had been satisfactorily resolved at this time and had become more or less irrelevant.

In the years immediately after the Great War, Ljubljana gained several long-awaited professional cultural and academic institutions of key national importance, including a university, a national theatre and a conservatory of music. Yet it was only the later nationalisation, that enabled Slovene musical culture to make gradual progress in the direction of the professionalisation and specialisation of musical activity, since with it conditions were finally met for the long-term work of some of the most important Slovene musical institutions.

38 Kogoj concluded his critical review of the work of the National Theatre Opera in Ljubljana in Dom in svet with the words:

"The younger generation awaits a solution to the question of nationalisation with perfect tranquillity, relying as it does on its capacity for work and the impulsiveness of its movement, and firmly convinced that its position is destined to be victorious."

Marij Kogoj, “Opera v prvi polovici sezone 1919/20," Dom in svet 33, no. 3/4 (1920): 98, http://www.dlib.si/?URN=URN:NBN:SI:DOC-8OoVSB2F. 


\section{Bibliography}

Anon. “Konservatorij 'Glasbene Matice," Slovenski narod 52, no. 214 (14 September 1919): 5. http://www.dlib.si/?URN=URN:NBN:SI:DOC-9RCZI5KT.

Anon. "Narodno gledališče." Slovenski narod, no. 288 (4 December 1918): 3.

Budkovič, Cvetko. Razvoj glasbenega šolstva na Slovenskem II: od nastanka konservatorija do Akademije za glasbo 1919-1946. Ljubljana: Znanstveni inštitut Filozofske fakultete, 1995.

Cigoj Krstulović, Nataša. Zgodovina, spomin, dediščina: ljubljanska Glasbena matica do konca druge svetovne vojne. Ljubljana: Založba ZRC, 2015.

Die Philharmonische Gesellschaft in Laibach, 20 October 1910, Ljubljana, Gesellschaft der Musikfreunde in Wien, Archiv.

Dolenc, Ervin. "Karel Verstovšek kot poverjenik za uk in bogočastje v narodni in deželni vladi v Ljubljani 1918-1920.” Časopis za zgodovino in narodopisje 66, no. 2 (1995): 284-291.

Gabrič, Aleš. "Ustanovitev Opere Narodnega gledališča v Ljubljani v sklopu izgradnje osrednjih narodnih kulturnih ustanov." Studia musicologica Labacensia 3 (2019): 275-287.

Hubad, Matej. “Jugoslovanski konservatorij Glasbene Matice v Ljubljani." Učiteljski tovariš 59, no. 35 (27 August 1919): 1.

Jeraj-Hribar, Vida. Večerna sonata. Spomini z Dunaja, Pariza in Ljubljane 19021903, po pripovedovanju zapisal Marijan Kovačevič. Ljubljana: Mladinska knjiga, 1992.

Juvančič, Friderik. “Sezona 1920-21.” Gledališki list Narodnega gledališča 1, no. 1 (1920-21): 12-14.

Kogoj, Marij. “Opera v prvi polovici sezone 1919/20.” Dom in svet 33, no. 3/4 (1920): 97-98. http://www.dlib.si/?URN=URN:NBN:SI:DOC-8OoVSB2F.

Koter, Darja. Slovenska glasba 1848-1918. Ljubljana: Študentska založba, 2012.

Krek, Gojmir. "Dostavek uredništva.” Novi akordi: glasbeno-knjićevna priloga 13, no. 1 (1914): 23.

Kuret, Primož. Ljubljanska filharmonična družba 1794-1919: kronika ljubljanskega glasbenega življenja v stoletju meščanov in revolucij. Ljubljana: Nova revija, 2005.

Lah, Špela. “Slovensko-nemška dihotomija v Deželnem gledališču v Ljubljani med letoma 1892 in 1914.” Muzikološki zbornik 46, no. 2 (2010): 95-108.

Lajovic, Anton. "Kulturni pregled: Naša glasbena kritika.” Jutro 10, no. 155 (6 July 1929): 6.

Matić, Dragan. Nemci v Ljubljani: 1861-1918. Ljubljana: Oddelek za zgodovino Filozofske fakultete, 2002. 
Moravec, Dušan, ed. Repertoar slovenskih gledališč 1867-1967. Ljubljana: Slovenski gledališki muzej, 1967.

“Podelitev pravice javnosti." Uradni list deželne vlade za Slovenijo II, no. 7 (16 January 1920): 30. https://www.sistory.si/cdn/publikacije/1-10oo/210/Uradni_ list_SHS_1920.pdf.

Tavčar, Ivan. “Slovenke in Slovenci!” Slovenski narod 51, no. 78 (6 April 1918): 1.

Vurnik, Stanko. “Glasba: Slovensko glasbeno življenje 1. 1928.” Dom in svet 42, no. 1-2 (1929): 63-64.

Weiss, Jernej. Emerik Beran (1868-1940): samotni svetovljan. Maribor: Litera, 2008.

Weiss, Jernej. Češki glasbeniki v 19. in na začetku 2o. stoletja na Slovenskem. Maribor: Litera and Univerza v Mariboru, 2012.

Weiss, Jernej. "Med provincialno opereto in nacionalno opero Foersterjev Gorenjski slavček." In Musica et artes: ob osemdesetletnici Primoža Kureta, edited by Jonatan Vinkler and Jernej Weiss, 59-75. Koper, Ljubljana: Založba Univerze na Primorskem, Akademija za glasbo, Festival Ljubljana, Slovenska filharmonija, 2015.

Weiss, Jernej. "Even Amidst the Clash of Conflict, the Sweet Sounds of the Muses did not Fade Away Completely: The Concert Life of the Philharmonic Society in Ljubljana in the Period of its Last Music Director Hans Gerstner." Muzikološki zbornik 53, no. 2 (2017): 149-171.

Zangger, Fritz. Das ewige feuer im fernen Land: Ein deutsches Heimatbuch aus dem Südosten. Celje: Druckerei u. Verlags AG, 1937. 